\title{
JISAE \\ EVALUATION ON THE IMPLEMENTATION PROGRAM OF NON- PERMANENT EDUCATORS ASSIGNATION AT THE EDUCATIONAL UNITS IN ALOR REGENCY
}

\author{
Alboin Selly \\ Universitas Tribuana Kalabahi \\ selly_alboin@yahoo.co.id \\ WardaniRahayu \\ Universitas Negeri Jakarta \\ Komarudin \\ Universitas Negeri Jakarta
}

\begin{abstract}
This study aims to evaluate the implementation of assignation program of non-permanent educators by the Educational Department in Alor using the CSE-UCLA model which consist of four stages namely needs assessment, program planning, formative evaluation and summative evaluation. A descriptive-qualitative method was applied with interview techniques, questionnaires, and documentation for the data collection. Based on the component of needs assessment, the program has a clear legal basis. However, since there is no technical guidance, therefore a different interpretation occurs during the implementation. Based on the program planning, the educational department has a program plan while the school needs aspect has not been fulfilled in terms of education degree and field of study. Formative evaluation, the assignation criteria for educators is based on school proposals using the administrative selection system. The placement of educators is not in accordance with the needs of schools based on the subject course. Summative evaluation, achievement of the program objectives has been attained in terms of quantity, although the improvements in terms of quality of assignation and placement of educatorare needed to be a concern to meet the school' needs.
\end{abstract}

Keywords: CSE-UCLA, Non-Permanent Educative Appointment Program, Program Evaluation.

\section{INTRODUCTION}

The progress of a region can be determined by how much the quality or quality of education in the area. This is because education has a strategic position in an effort to improve human resources to improve the quality of life of the community. Recognizing the importance of the process of improving the quality of human resources, the government has and continues to realize the mandate of the law through various educational development efforts of higher quality, among others through the development and improvement of curriculum and evaluation system, improvement of education facilities and infrastructure, development and procurement of materials teaching, and training for teachers and education personnel on an ongoing basis.

Alor regency as one of the districts that fall into the category of area $3 \mathrm{~T}$ (Front, Outermost, Disadvantaged). As a $3 \mathrm{~T}$ area, it will still require central government intervention in all fields in terms of education, infrastructure, and economic improvement of the community. Yustina and Dahnilsyah (2015) describe the emerging issues of education in $3 \mathrm{~T}$ areas, among others, the lack of teachers, unequal facilities and teaching staff, low qualification standards, unskilled faculty and educational background of teachers. In line with these ideas, the fulfillment of teachers is a necessity in the field of education as an effort in improving the quality 
of education that affects the quality of human resources.

Teacher fulfillment efforts in Alor district cannot run maximally, due in August 2011 issued by SKB Minister of Home Affairs, Minister of Finance and Minister of State Apparatus About moratorium of CPNS Receipts which came into effect in September 2011. Policy through SKB This Minister is because central government assesses expenditure employees are generally much larger than public spending or the budget used for public services and development. As expressed by Dharmaningtias (2016), personnel expenditure in 294 districts/cities across Indonesia is more than 50 percent APBD In 116 districts/municipalities even more than 60 percent. In fact, there are areas that allocate personnel expenditure of more than 70 percent of the APBD.

In order to meet the needs of educators in Alor district, the local government issued a program through the Alor Regent's Decree on the Appointment of NonPermanent Educators and Non-Permanent Education Personnel In Education Unit in Alor Regency aimed at addressing educational issues especially the shortage of educators, providing experience of dedication to the bachelor education to form a professional attitude and skilled in an effort to improve the quality of education. The program received a positive response from the community because the program was made completely in the name of the public interest to address the problem of education in meeting the needs of teachers.

Non-Permanent Education Teachers and Non-Permanent Education Officers In Education Unit in Alor District through Bupati's Decree, in the implementation phase, there is often a clash of both non-permanent educators, non-permanent educators with the education office as implementers of the non-permanent appointment program. This is because the first, the process of appointment, which is considered some educators are not fixed with no indication of the maximum or in line with expectations. Secondly, the Budget, the amount of honor received by the non-permanent educator also becomes the problem due to the logical consequence of a decree. Third, the placement of non-permanent educators also faces problems because of differences in understanding between non-permanent educational staff and the education office.

The description of the reality of the appointment program of the nonpermanent educator is a required evaluation because, in the implementation of a program, the component that determines the success of a process is an evaluation. This is because through the evaluation will be known to what extent the implementation of the program, program objectives, and a program can be achieved in accordance with the desired goals. Mardapi (2009) describes the evaluation of the program contains the meaning of information gathering activities, drawing, searching and presenting information in order to make decisions about the program implemented.

In relation to the importance of this study, researchers used the evaluation model of the Center Of California in Los Angles (CSE-UCLA) which directed the evaluation objectives of the program on the four process components of a program. Considering the selection of the model because the evaluation model of CSEUCLA has 4 (four) stages: needs assessment, program planning, formative evaluation and summative evaluation (Fernandes, 1984).

The evaluation result using CSE-UCLA model aims to give a 
recommendation to the local government through the education office of Alordistrich to make the decision on the appointment program of the nonpermanent educator whether the program continues to be feasible to continue, it needs improvement and improvement or discontinued.

\section{METHOD}

This research is an evaluative research with the aim to know the effectiveness and appropriateness of the implementation program of appointment of non-permanent educators based on predetermined criteria and objectives. The approach used in this research is the qualitative approach, the method used is descriptive-qualitative with research design based on CSE-UCLA evaluation model proposed by Fernandes (1984) consists of four components namely: needs assessment, program planning, formative evaluation, and summative evaluation. This evaluation study used interview techniques, questionnaires, and documentation for the benefit of data collection. While the informant of the research is the education office as the owner of the program, the chairman of the DPRD and educators are not fixed. Analysis of the data using the model of Miles and Huberman (Sugiyono, 2007) suggests three steps in the analysis of qualitative data, namely data reduction (reduction of data), the data display (presentation of data), and Verification (verification).

\section{Needs Assessment}

\section{Legal program}

the basis of theBased on data obtained through interviews and documentation studies, it is explained that the appointment program of non-permanent educators is one of the local government programs implemented by the Education Office since 2011. The presence of the appointment program of non-permanent educators as government efforts areas in providing educators who have competence, both in terms of educational qualifications strata one (S1) education and the suitability between the field of science and subjects that to be taken with a view to meet the needs of schools.

The results of the District Education Office interview: "The steps taken by the local government and the local parliament in implementing the educational appointment program are not fixed based on educational needs in the regions". The same statement was submitted by Alor Regency DPRD: "This program is based on the needs of educators so that we assess the need for the appointment of qualified educators who are at least strata-one level".

Referring to interview data, the presence of a non-permanent appointment program is a logical consequence of moratorium or temporary cessation of CPNS acceptance nationally, many retired civil servants every year, resulting in a gap between educators and school needs. Beyond the other, national policies related to the expansion and equitable access to quality education require that local governments be required to open new schools with a view to accommodating school-aged residents which would have an impact on APK and APM to measure the quality of education in an area. Thus, a non-permanent educator program is a solution to meeting school needs and addressing national and local policies in 
relation to the expansion of quality educational access.

Based on education needs in the region, the local government formulates legal products as legal umbrella program with the purpose of clear legal program ground, will avoid misinterpretation and can be a reference for the parties involved in the implementation of the program so that the objectives of the established program can be achieved.

Implementation of the Non-Permanent Educator Appointment Program has a clear regulation as the legal basis in the form of KEPMEN, PERDA or Alor Regent's Decree as a foothold in performing tasks as educators in schools. Based on the Decree, it implicitly explains that the appointment program of nonpermanent educators established to meet the needs of the community in the field of education, especially the availability of educators in schools. Thus, the nonpermanent appointment program of educators carried out by the Alor District Education Office, on the aspect of regulation or legal foundation, has met the established criteria. With clear legal program foundation, the implemented program can gain the achievement of program objectives that impact on the quality of human resources and can encourage the quality of education in Alor District.

\section{Guidelines for program implementation}

In general, each program that will be implemented has implementation guidance as a reference in implementing the program so that the program created transparent and accountable activities management, so have a common understanding in implementing the program directed to the program implementation mechanisms to the program objectives to be achieved.

Based on the results of interviews with the Education Office, "There are guidelines for the appointment of educators and education personnel who have been prepared and have been implemented and also given because there are formulated in the Decree of the Regent that regulates the rights and obligations of the parties". In addition to the data obtained through interviews, researchers also get information about the implementation guidelines through the distribution of questionnaires.

E YA $=$ Tidak

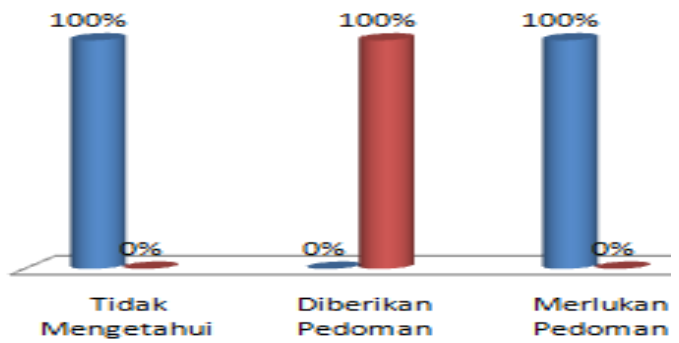

Figure 1. Program Implementation Guidelines

The research results show that the appointment of non-permanent educators conducted by the Education Office does not have technical guidance or technical guidance for the implementation of the program so that there is no uniformity in 
implementing the program by various parties involved in the appointment of nonpermanent educators. So far, the program is implemented according to the knowledge and understanding and direction of the Head of Education Office which is adjusted with the Decree of the Regent. If the Bupati's decision on the program implementation process and the scope of the program are regulated in general, the DinasPendidikan as the program implementer should translate the legal product in a guideline or technical guidance as a guidance for the parties involved in the program. The guidelines contain program background, program objectives, program objectives, implementation procedures, budget and monitoring and evaluation system. Furthermore, the guidelines have been made disseminated or given to the parties involved so that the mutual understanding in implementing the program of appointment of educators is not fixed. If the program implementation guidelines are not made as a guideline and a shared understanding of the parties involved in the program, otherwise the program will not achieve the optimal achievement of the program objectives even the program will run stalled because the parties involved in the program will implement the program in accordance with the understanding and experience of each, of course, affect the success of the program, without any program implementation guidelines.

\section{Objectives of the program}

Based on data obtained through documentation studies of documents relating to the program objectives, it was found that the purpose of an irregular educator appointment program is not specifically regulated in the manual or technical manual but is contained in the Bupati's Decree on the Appointment of Educators and Non-Permanent Personnel Year 2018. While the results of interviews about the purpose of the program, the Office of Education revealed that "The purpose of the program fulfillment of educators and education for the needs of schools."

Referring to the data documentation and interviews, it is known that the program has a program object that is to meet the needs of Educators and Education Personnel on units of Early Childhood Education and Basic Education Levels as well as in the Alor District Education Office. Furthermore, researchers also obtained data from educators not fixed about the purpose of the program through the questionnaire as follows.

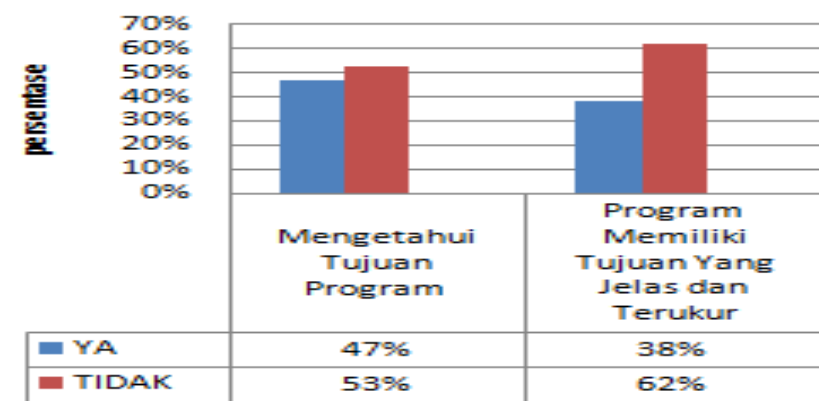

Figure 2. Aspects of Program Objectives

Thus, it can be said that although the program has the purpose of the program, most of the respondents who are also parties involved in the implementation of the program do not know the purpose of the program. In addition, the purpose of the appointment program of educators is not fixed needs to be improved by 
considering the criteria for the formulation of objectives that are more specific, measurable, achievable, in accordance with reality and time-bound. This is because based on interviews and documentation studies the program objectives are still limited to the fulfillment of educators against the needs of schools without considering the qualifications of educator education. In terms of qualifications educators can realize the process of education and be learning to achieve the goals of national education, as set out in Law RI No. 14 of 2005 on teachers and lecturers in Chapter I mentions that teachers must have a qualified academic, competence, educator certificate, healthy physical and spiritual, and have the ability to realize the goals of national education. Further on Article 9 the qualifications referred to in article 8 shall be obtained through higher education or undergraduate diploma program. Referring to the Act, it expressly requires teachers to have a Strata 1 or four diploma qualification and have a background in accordance with the discipline. For that, the formulation of the purpose of the appointment program of educators is not fixed need to consider the qualifications of educators, because basically, the qualifications of educators are factors that influence and determine the success of the program. Because without the qualifications of educators in the formulation of the objectives of the program will bring a very meaningful effect on other aspects such as aspects of appointment and placement of educators which would have an impact on the success of the program.

\section{Program targets}

Based on the results of interviews with the Office of Education, stated that "The target of the first non-permanent appointment program, the fulfillment of short-term needs that meet the needs of the school while the second achievement of Vision and regional missions".

In the framework of responding to program objectives, in the implementation of the program until the fiscal year 2018, the local government has appointed and assigned educators to be placed in schools.

Table 1. Number of Schools Target Program

\begin{tabular}{clcccc}
\hline No & \multicolumn{1}{c}{ Subdistrict } & $\begin{array}{c}\text { Early } \\
\text { Childhood }\end{array}$ & Primary & $\begin{array}{c}\text { School } \\
\text { Junior } \\
\text { High }\end{array}$ & $\begin{array}{c}\text { Number } \\
\text { of }\end{array}$ \\
\cline { 3 - 5 } 1 & Teluk Mutiara & 24 & 27 & 13 & 64 \\
\hline 2 & Kabola & - & 11 & 4 & 15 \\
\hline 3 & North Central Alor & - & 18 & 7 & 25 \\
\hline 4 & Overtime & - & 10 & 3 & 13 \\
\hline 5 & Alor Northeast & - & 13 & 6 & 19 \\
\hline 6 & Alor Timur & 3 & 21 & 7 & 31 \\
\hline 7 & Pureman & 1 & 9 & 3 & 13 \\
\hline 8 & Alor Selatan & 2 & 19 & 7 & 28 \\
\hline 9 & Mataru & - & 13 & 3 & 16 \\
\hline 10 & Alor Barat Daya & 4 & 34 & 17 & 55 \\
\hline 11 & Alor Barat Laut & 4 & 22 & 15 & 41 \\
\hline 12 & Pulau Pura & - & 7 & 3 & 10 \\
\hline
\end{tabular}




\begin{tabular}{clcccc}
\hline 13 & Pantar & - & 14 & 11 & 25 \\
\hline 14 & East Pantar & 2 & 19 & 8 & 29 \\
\hline 15 & Pantar Tengah & 1 & 15 & 7 & 23 \\
\hline 16 & West Pantar & 1 & 8 & 4 & 13 \\
\hline 17 & Northwest Pantar & - & 4 & 5 & 9 \\
\hline & TOTAL & 42 & 264 & 123 & 429 \\
\hline
\end{tabular}

Referring to the table, it can be inferred that in the aspect of the target of the appointment of non-permanent educators conducted by the DinasPendidikan has fulfilled the criteria that have been formulated in the previous section that is to provide non-permanent educators strata one in accordance with the level of early childhood education and basic education level.

\section{Program Planning Program implementation plan}

Interview with DinasPendidikan that prior to the appointment of nonpermanent educators, the DinasPendidikan held a coordination meeting and consultation with the parties who had relevance to the program to plan and discuss the implementation of the program. Quotations from interviews related to program planning are as follows: "first, discuss recruitment plan for teachers and educators; second, establishing a committee with the task of recruiting the selection of educators, organizing and managing and fostering non-permanent educators; third, the components involved in the committee are the secretary of the education office, the Head of Education and Education Personnel (PTK), Head of Paud Field, Head of Primary School, Head of SMP, Head of Sub Division of Personnel and Head of UPT; Fourth, propose the names of the committee be given SK by the Bupati; Fifth, formulate the main tasks and functions of the committee in implementing the program of appointment of non-permanent educators; Sixthly, discussing the proposals of Head of School and Head of UPT related to educational staff; and Seventh, discusses and establishes the source and amount of budget for one fiscal year.

Based on the data, it can be said that the Education Office coordinates and consults with various parties to hear and discuss the plan of program implementation.

\section{Formative Evaluation Appointment system}

So far, the Department of Education has appointed non-permanent educators as many as 1533 educators spread across 429 schools out of a total of 598 schools in 17 sub-districts.

Table 2.A number of Teachers and Educational Year 2018.

\begin{tabular}{ccccc}
\hline No & District & Educators & education personnel & Number \\
\hline 1 & Gulf Pearl & 301 & 248 & 549 \\
\hline 2 & North Central Alor & 101 & 85 & 186 \\
\hline 3 & Overtime & 46 & 49 & 95 \\
\hline 4 & Kabola & 65 & 79 & 144 \\
\hline 5 & Northeast Alor & 57 & 69 & 126 \\
\hline 6 & Alor East & 84 & 118 & 202 \\
\hline
\end{tabular}




\begin{tabular}{ccccc}
\hline 7 & Pureman & 38 & 54 & 92 \\
\hline 8 & Alor Selatan & 79 & 133 & 212 \\
\hline 9 & Mataru & 41 & 64 & 105 \\
\hline 10 & Alor Southwest & 189 & 178 & 367 \\
\hline 11 & Northwest Alor & 168 & 162 & 330 \\
\hline 12 & Pulau Pura & 33 & 42 & 75 \\
\hline 13 & Pantar & 83 & 77 & 160 \\
\hline 14 & Pantar Timur & 93 & 66 & 159 \\
\hline 15 & Central Pantar & 86 & 72 & 158 \\
\hline 16 & West Pantar & 33 & 29 & 62 \\
\hline 17 & Pantar & 36 & 51 & 87 \\
North & Total & $\mathbf{1 5 3 3}$ & $\mathbf{1 5 7 6}$ & $\mathbf{3 1 0 9}$ \\
\hline
\end{tabular}

Based on data obtained from the Education Office, it is known that the system or appointment mechanisms have undertaken by the Office of Education uses an administrative selection system. With the system of administrative selection in the application, there are still constraints such as the element of subjectivity and inaccuracy that affect the quality of appointment of non-permanent educators who are appointed as educators in carrying out the task of learning in the classroom. Therefore, the aspect of the appointment system requires the policy of selection in stages or in other words after the selection of administration, followed by a written selection or interview. As more levels of selection are done, the more careful and meticulous they can be to produce competent educators according to the school's needs. The theory presented by Nawawi (2000) describes the planning of human resources with the orientation of the results of job analysis so that the necessary workers can be fulfilled both in terms of quantitative and quality.

Siagian (2008) argues that there are at least eight steps to consider in the recruitment process: acceptance of the application, examination, selection interviews, background checks of applicants and referral letters, health evaluation, interviews by managers who are direct supervisors, and the decision on the application. The steps presented by Siagian are associated with the mechanism of appointment of non-permanent educators conducted by the Alor District Education Office there is a difference because the appointment mechanism applied by the DinasPendidikan does not open vacancies and receive a cover letter but the appointment is made on the proposal of the school and the education office undertakes selection of administrations based on the proposal without conducting exams and selection interviews. Yet by using the appointment mechanism offered by Siagian, it directly provides an accurate picture of the educator's self in completing the main task and function given as an educator. it is done in order to be able to find educators who are in accordance with the expected school needs and have a good performance in completing the task.

\section{PlacementThe placement}

Mechanism in question is an act to organize educators to occupy a particular school based on the suitability of school needs and the competence of the field of 
candidates for educators. Failure in placing educators will lead to various things such as the implementation of ineffective and efficient learning activities that certainly have an impact on the goals and objectives of the program. therefore, the aspect of the placement of non-permanent educators is an important part in the implementation of the appointment program of non-permanent educators, since in general the placement of a person is usually done based on follow-up of the recruitment result or also based on the needs of each school followed up by the granting of SK Bupati .

From the data obtained through interviews with DinasPendidikan it is known that the placement mechanisms conducted by the DinasPendidikan are based on the results of recruitment of non-permanent educators through the proposal of the principal and then the proposal in comforter with the official data related to the analysis of school needs to be based on the teacher distribution map in each school.

As many as 1533 teachers have been placed in schools, it is found that the placement of non-permanent educators does not meet the needs of schools based on the field of study. This is because even though in terms of quantity of educators have fulfilled the schools but in terms of quality has not met the needs of schools, so there are still excess teachers in certain areas of study and on the other hand there is a shortage of educators in other fields of study. The results of the researcher based on questionnaires showed that 150 respondents of non-permanent educators in 71 schools consisting of 38 elementary and junior high schools amounted to 33 schools, it was found that there were schools that did not have educators in accordance with the subject area or subjects, there is a surplus of a particular field of study and a lack of other fields of study. for more details can be seen in the picture below.

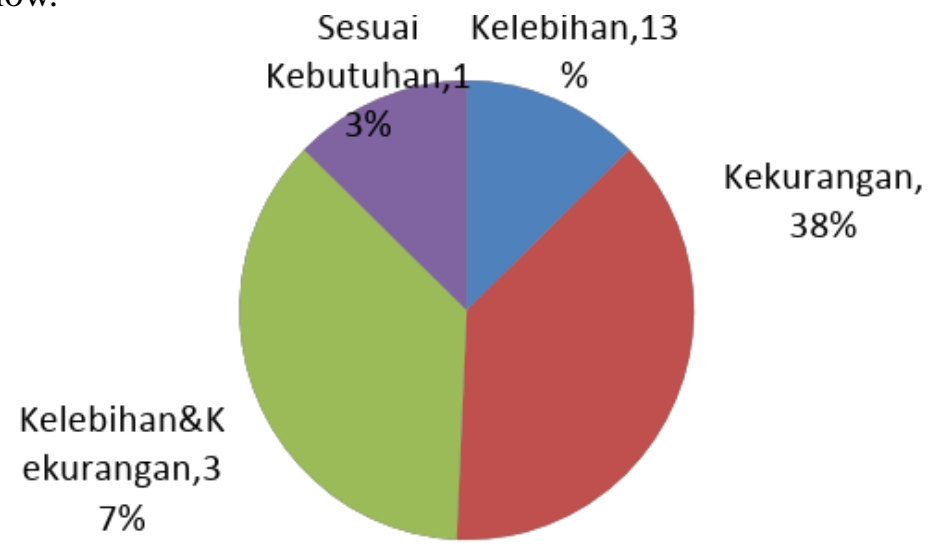

Figure 3. School Needs by Field of Study at Primary and Junior High School level.

The diagram shows that the number of educators placed in schools has not met the needs of the school based on the competence of educators in the subject areas or subjects required by the school. For example, SD Gmit 23 Takalelang educators who placed as many as 7 people and there is an excess or accumulation of educators/teachers of study/subjects PJOK and PAK. In another dish, the lack of 
educators occurred in the SD Inpres West Kalabahi IV educators who placed as many as 8 people but the school is still short of educators/teachers subject/subjects PJOK.

Another thing that researchers find in the field, there are schools that on the placement of educators still occur excess of certain subjects and other shortcomings, such as the placement of educators in GMIT 31 Mainang elementary school is not in accordance with the needs, because educators who placed there excess eye teacher PAK and PJOK lessons and there is a shortage of classroom teachers. There is also a place of educators who are in accordance with the needs of schools such as SD GMIT 004 Lawahing. The condition of this placement also occurs the same thing in junior high school.

Based on research data related to the placement aspect of educator, it is concluded that the placement mechanism done so far is based on the follow-up of the recruitment outcomes in which the recruitment mechanism through the school proposal but in the placement of educators not yet in accordance with the needs of schools based on the field of study. Data related research placement educators indicate that the suitability of educational background and educator placement has not fulfilled the provisions of the Teachers and Lecturers Law of 2005 Article 7 paragraph 1c on professionalism that the profession of teachers and professors of lecturers is a special field of work carried out based on the principle of having academic qualifications and educational background in accordance with task field. The results of research on the suitability of the field of study or subjects that are potent with the placement of educators according to the needs of schools there are still educators who take care of other subjects that are not part of the educational discipline concerned with the reasons of the lack of teachers of certain subjects, due to the placement of educators in accordance with the needs the school based on the discipline is still about $13 \%$, thus the placement of educators who have not been in accordance with the needs of the school based on the study by $87 \%$.

As explained by Daniel, Sanda and Mindala (2014: 66) placement is the process of putting people into certain positions who have been selected for the job. Referring to that opinion, in the process of placing the educational background, the skills of the educator must be in accordance with the work specified. In line with the Team Lecturer AP-UNY (2011: 70) that the basic principles of placement and assignment of employees is the suitability of duties and abilities possessed employees. Therefore, field results related to the placement of educators, educational backgrounds, with the subjects that are potent is one reference in the placement of educators.

\section{Summative Evaluation}

The results of the study show that up to 2018, local governments have appointed and assigned non-permanent educators and education personnel as many as 3019 people in the Early Childhood and Basic Education and Education Environments. The data shows in terms of quantity has been met but in terms of quality is not in accordance with the needs of schools. An excerpt from an interview from the Department of Education revealed that "Not all schools have educators who have S1 education and teaching according to the discipline that the educator has" While DPR "We Parliamentary school staff educators who are in 
school there are also non S1 education there is a graduate High school, there are also educators who teach is not in accordance with the disciplines that they have. The same information also researchers found in questionnaires distributed to educators.

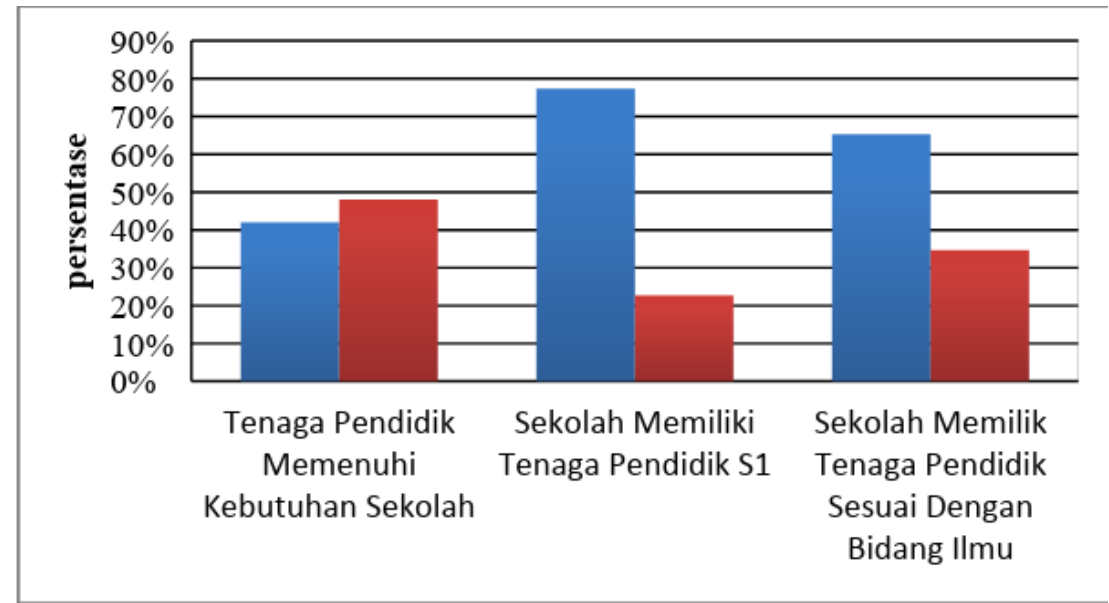

Figure 12. Aspects of Achievement of Program Objectives

Based on the data obtained related to the achievement of program objectives can be said that in terms of quantity is in accordance with the criteria but there need to be improvements in terms of quality of appointment and placement of educators in accordance with the needs of schools due to the appointment and placement educators in accordance with the needs of schools will encourage an effective learning process which certainly impacts on the quality of education in Alor District.

\section{CONCLUSION}

In the stage of needs assessment consists of four aspects evaluated namely, the legal basis of the program, the guidelines for program implementation, goals and objectives of the program. Based on the evaluation results, at this stage, most do not meet the criteria of success that have been set. For the aspect of legal foundation, has fulfilled the criteria of success, while the other three aspects of the program implementation guidelines, goals and objectives of the program have not met the criteria of success.

At the stage of program planning. For aspects of the program implementation plan is in accordance with the established success criteria. As for the aspect of school, needs has not met the criteria of success.

For the stages of formative evaluation, in general, have met the criteria of success, but there are some aspects that need to be improved and improved especially on aspects of appointment system and placement mechanism.

At the stage of the summative evaluation has met the criteria of success but needs to be improved again in the aspects of appointment and placement so that educators who are appointed and placed in accordance with the needs of schools based on the strata of education and field of study.

\section{REFERENCES}


Creswell, John W, Research Design: Qualitative, Quantitative, and Mixed Methods Approaches. California: SAGE Publications, 2009.

Cummings, Rick, What if: The Counterfactual in Evaluation Program. Evaluation https://www.aes.asn.au Journal Australasia, Vol.6, Spring 2006 (accessed July 27, 2017).

Daniel, A. Sanda, AA, \&Midala, AS Recruitment, Selection And Placement Of Human Resource In Adult And Education Organisation: Implications For The Management Of Adult Education Borno State Nigeria. Journal Of Education and Practice. Vol.30, No.2, 2014.

Dinas Pendidikan Kabupaten Alor, Dokumen Perencanaan Program Pengangkatan Pendidik dan Kependidikan Tidak Tetap, Tahun 2018.

Dinas Pendidikan Kabupaten Alor, Dokumen Pelaksana Anggaran, Tahun 2018.

Fernades, HJX (1984). Evaluation of educational programs. Jakarta: National Education Planning, Evaluation and Cultural Development.

Mondy, W. Noe, R. M, \&Premeaux, SR, Human Resource Management.United State of America: Pratince Hall International, 1999.

Nawani, H, Manajemen Sumber Daya Manusia Untuk Bisnis Yang Kompetitif. Yogyakarta: Gaja Mada University Press, 2000.

Proponsi Nusa Tenggara Timur Keputusan Bupati Alor, Pengangkatan Pendidik Non-PNS Daerah Serta Tenaga Pendidikan Intensif Daerah Pada Satuan Pendidikan Di Kabupaten Alor, TahunAnggaran 2018.

Siagian, SP, Manajemen Sumber Daya Manusia, Jakarta: BumiAksara, 2008.

Yustina and Danilsyah, Manajemen Kurikulum Program Profesi Guru Untuk Daerah, Jurnal Pendidikandan Kebudayaan, Creatifity of SM3T Participans at Riau University In Developing Knowledge Using Project-Based Learning at Lany Jaya, Papua, Indonesia, 9 (31) 5036.

Worthen, BR \& JR Sanders. Educational Evaluation: Theory and Practice. California: Publishing Company, 1973.

Tim Dosen Administrasi Pendidikan Universitas Negeri Yogyakarta, Manajemen Pendidikan. Yogyakarta: UNY Press, 2011.

Undang-Undang Republik Indonesia No 14 Tahun 2005 \& Peraturan Menteri Pendidikan dan Kebudayaan Republik Indonesia Tahun 2014 Tentang Guru dan Dosen. 